\title{
Financial accountability, ethical issues and organizational citizenship behavior in fragile economic systems: The case of the Nigerian economy
}

\author{
Remi Chukwudi Okeke $^{a^{*}}$ and Linda Oluchi Nwankpa ${ }^{b}$
}

${ }^{a}$ Department of Public Administration and Local Government, University of Nigeria, Nsukka, Nigeria ${ }^{b}$ Department of Accountancy, Abia State Polytechnic, Aba, Abia State, Nigeria \begin{abstract}
A B S T R A C T
The general objective of this study is to examine the relationship among financial accountability, ethical issues and organizational citizenship behaviour, in a national economic system. The null hypothesis of the study examined the inverted trajectories of the variables. The work is situated within the context of Nigeria's national economy, which typifies a fragile economic system. We have argued in the work that the fragility of the Nigerian national economic system (which is representative of similar economies among developing nations) is a function of its input-output processes. The study essentially finds that to reverse the trend of fragility in an economic system (a national economic system) in the context of developing economies, the issues of financial accountability, ethical questions and great organizational citizenship behaviour must in their combinatory format, be elevated to the status of a national imperative. We found in the work, that ethical regeneration is antecedent to institutional reform, in the schemata of mechanisms, for reversing the tendency of fragility, in troubled economic systems, classifiable as developing or underdeveloped.
\end{abstract}

\section{Introduction}

The Nigerian national economy has remained in historical terms, a theater of immense turbulence. Invariably, the economic entities in the country (and the other public sector organizations) are characteristically troubled. What then are the central tendencies that drive the lives of these organizations? What are the dominant predispositions that shape the worldviews of the personnel of the organizations? How do the workforces of these institutions perceive finance and the role of finance in organizational productivity (and by extension, in national economic prosperity) and inclusive progress for all citizens? In the nature of the chicken and egg puzzle, which truly comes first, institutional reform or ethical regeneration? These are the central research questions of this investigation. The typology of the research is qualitative. We have accordingly relied on secondary sources of data for our analysis. We have also employed the methodology of logical argumentation to arrive at our findings and conclusions. The theoretical framework of the study is the systems theory. 


\section{Theoretical framework of the study: Systems theory}

Citing Das Hara and Chouldbury (1997, p.19), Mbah (2014, p.106) highlights that the writings of Ludwig Von Bertalanffy (a biologist) in the 1920s on the general systems analysis, have been of considerable importance, in the development of the systems theory. Consequently, posits Mbah, the abstract part of the theory is traceable generally to the natural sciences, especially to biology. In the same vein, Izueke (2014, p.161) posits that Bertalanffy (1951) propounded that a general systems theory (GST) existed, which could be applied in nature, business contexts, organizational or economic systems. Systems theory therefore usually provides an interdisciplinary template of scholarly investigation. It alludes to the interdependence of composite units of nature, business sub-divisions, organizational sub-structures and sundry sub-systems, to form the whole that is describable as the specific system. A critical aspect of the theory in its evolution, is accordingly the input-output function.

Mele et al (2010, p.126) on their part have cited Bogdanov (1922 / 1980), Von Bertalanffy (1968), Lazlo (1996), and Meadows (2008), to argue that since Aristotle's claim that knowledge is derived from the understanding of the whole, and not that of the single parts (Aristotle's Holism), researchers have been struggling with systems and parts, in terms of their contents and their relative dynamics. Moreover, that this historic effort evolved during the last century, into so-called "systems theory". Also citing Capra (1997), Mele et al. (2010), posit that systems theory is an interdisciplinary theory about every system in nature, in society and in many scientific domains, as well as a framework with which we can investigate phenomena, from a holistic approach. Von Bertalanffy on his part argues that a more detailed investigation would rather enumerate a long array of thinkers who must have contributed notions to what is currently called systems theory. He argues that in hierarchic order, we are actually using a term introduced by the Christian mystic, named Dionysius Aeropagite, who although, was speculating about the choirs of angels and the organism of the church (Von Bertalanffy, 1972, p. 407). The origin and evolution of the systems theory thus, also finds relevance and essence, in the context of its own system. It has however certainly become a construct of multidisciplinary import, in scientific investigation.

In framing this work on the systems theory therefore, we contend that the fragility of a national economic system is a function of the input-output processes of the systems theory. Thus, when what is inputted is an immense lack of financial accountability, certain monumental decibels of ethical impropriety, and some substandard measures of organizational citizenship behaviours, the product would invariably translate to fragilities in the economic system. We have treated the Nigerian economy in the study, as a composite of immensely manifold organizations. Moreover, the generic national economic system is also denoted in the study as an organization. Furthermore, according to Stichweh (2011), systems theory is a science, which has the comparative study of systems as its object. Our study is thus interested in the inherent comparison between fragile economic systems and the stable types of national economic systems.

\section{Fragility of the national economy in Nigeria: Turbulent narratives}

We view a fragile economic system in this study as the type that is not headed for any definable ideological destination (neither state-centric, neither capitalist nor accurately describable as welfarist). The structural foundations of such economic systems are eternally weak and they are found mainly among the so-called developing countries, which are unendingly developing. The Nigerian economic system is thus classifiable under such perpetuities of fragility. Hence, according to AbdulLateef(2007), the Nigerian economy was sustained by agriculture as the main foreign exchange earner from 19601970 (accounting for about 76\% of the country's Gross Domestic product, GDP). The country was then the world's largest producer and exporter of palm oil and groundnuts. With the ability to export $47 \%$ of her products, AbdulLateef continues, Nigeria contributed $18 \%$ to the world's total exports and additionally remained a force to reckon with, regarding such other crash crops as rubber, cotton, citrus 
and peanuts. Today however, the country is a net importer of everything, inclusive of second-hand clothing materials and numerous types of other inner-garments.

Still on another front, it is estimated that the Nigerian nation needs some $153,000 \mathrm{MW}$ of electricity to sustain the economy (the national economic system) and to survive as a modern-state. But in the third quarter of 2017 , the country is celebrating the generation of $6,863 \mathrm{MW}$ as a national achievement (Oladeinde, 2017). Power supply to sundry businesses therefore remains convulsive in the country. It keeps exhibiting symptoms of epileptic fits. Private sector organizations, which find it increasingly difficult to run their businesses on gasoline (usually obtained at exorbitant prices) do finally, decide to lay off their workers where they fail to close shops completely. Consequently, the unemployment situation in the country keeps getting more complicated. Asaju et al. (2014, p.12) in this regard describe the incidence of unemployment in Nigeria in the 21 st century, as alarming. The rates of unemployment, they argue, keep on rising without spirited efforts on the part of the relevant authorities to embark on purposeful action. Available statistics for Q4 2016 thus indicate a youth unemployment/underemployment position of $47.40 \%$ for the country. And we do think that the unemployment / underemployment scenario in the country is largely illustrative of the upsetting fragilities in the national system.

\section{Table 1}

Unemployment/Underemployment Indicators in Nigeria for Q4 2016

\begin{tabular}{lr}
\hline Unemployment & $14.2 \%$ \\
Underemployment & $21 \%$ \\
Youth Unemployment/Underemployment & $47.40 \%$ \\
\hline
\end{tabular}

Source: National Bureau of Statistics (NBS)

According to Onuoha $(2008$, p.5) therefore, Nigeria has experimented with all kinds of ideologies and economic management theories to move the economy of the nation forward to no avail. In April 2014 for instance, the country was said to had "rebased" its gross domestic product (GDP) data, which thus pushed it ahead of South Africa, as the biggest economy on the African continent (BBC News, 2014). By August 2016 however, the same country had slipped into a recession, after witnessing two consecutive quarters of receding growth, the invariable definition of economic recession (BBC News, 2016). Hence, the generic system begins to incline inevitably towards the paroxysmal tendencies of the national energy sub-system, akin to the input-output processes of the systems theory. As we conduct this study (precisely after twelve calendar months), words are not yet coming from the relevant quarters in the country, to indicate the trend in the extant receded economic fortunes of the national system.

The thesis of Onuoha (2008, p.5), about a nation that has experimented with all kinds of ideologies and economic management theories to move the economy forward to no avail, accordingly continues to play out. Development, in all its facets, has accordingly remained a mirage in the country, in spite of the favourable human and material resources-endowment of the country (Ishaq, 2014, p. 37). While there are self-evident instances of deepening hunger and starvation, and skyrocketing trend in prices of commodities (and the prices of sundry goods and services in the national economy), the official figures usually assume that the economy is still doing well (under an economic recession). What the Nigerian officialdom sees and says and what the subaltern class of citizens think about the system, have accordingly continued to diverge in immense proportions.

Then according to Amaefule and Umeaka (2016, p.8), the economic impoverishment of the ordinary Nigerians (occasioned by gross dilapidation of the nation's infrastructure, poor health facilities, deathtrapped roads, general insecurity and overbearing hardship of the common man, in the face of the government's huge annual budgetary provision, year after year), is indeed worrisome. In addition, this, no doubt, is attributable to endemic corruption, in the Nigerian national system. Furthermore, in these 
regards, what the sleazy official does and the unwholesome tendencies of the average citizen also, immensely contribute to the scenario we characterize as marking turbulent narratives in this study. We consequently focus further on the contribution of organizational citizenship behaviour, to the germane issues in this study.

\section{Organizational citizenship behavior in Nigeria: Financial accountability and ethical issues}

What is organizational citizenship behaviour? Jahangir, Akbar \&Haq (2004, p.75) see organizational citizenship behavior (OCB) as the set of discretionary workplace behaviors that exceed one's basic job requirements. These scholars highlight that OCBs are described often as behaviors that go beyond the call of duty. Implicit in this connotation therefore, is that organizations could not survive or prosper without their members behaving as good citizens, by engaging in all sorts of positive behaviors (Jahangir et al., 2004, p.75). Then Walz and Niehoff (1996) in Jahangir et al. (2004, p.76), highlight that OCB denotes a set of desirable organizational behaviors, which demonstrate multi-dimensional relationships with positive organizational outcomes. Then citing Organ (1997), Takeuchi et al. (2015, p.1239) define organizational citizenship behavior (OCB) as employee behavior that is relatively discretionary and contributes to the maintenance and enhancement of the social and psychological context that supports task performance. In the context of this study, we refer to national (nationalistic) task performance. We are also alluding to behavioural patterns of good citizenship in a country.

We consequently argue that organizational citizenship behaviour in Nigeria is rendered cumbersome and anti-establishment, by the duality of ethical improprieties and the generic dearth of financial accountability in sundry organizations in the country. These deficiencies have also become the central tendencies that drive the lives of these organizations. Historically, the incidence has continued to be researched as an issue of corruption. It seems to us however, as if the nomenclature of corruption has lost all its frightening and horrendous weightiness in this socio-economic system (Nigeria). We acknowledge the fact that what is called corruption, is universally difficult to define. Then under the Nigerian scenario, not only that the deplorable phenomenon has remained thorny to conceptualize, it has also remained hard to defeat in empirical terms. Inversely, corruption seems to be defeating elected officials in Nigeria. The current Nigerian President, Muhammadu Buhari, was for instance, sworn in on 29 May 2015. He has since spent a total of 152 days on medical vacation (Salauden, 2017, p.7). And he has certainly become an unhealthy President, immensely incapacitated by his extant physical status, to prosecute the onslaught against corruption in the country. (The fight against corruption was a major item in the template of the President's electioneering campaign promises).

It has accordingly been supposed (perhaps humorously), that the Nigerian leader became ill on realizing that the level of corruption in the country has assumed an insufferable status (DTN, 2017). According to Ekpo et al. (2016, p.69) therefore, instead of tackling corruption, the Muhammadu Buhari administration in the country, has been busy running after the manifestations of the problem, with so much enthusiasm that such actions will deter others from exhibiting such traits of sleaze. What the administration and the ones before it have invariably failed to factor into their anti-corruption templates are accordingly a central matter in the current contribution. Hence in this work, we table financial accountability as focus of study (in place of corruption), and introduce the concept of ethical issues (their deficiencies), as the alter ego of the death of financial accountability in the schemata of questions that render comatose organizational citizenship in the Nigerian economy. We are inclined to think in this study that merely theorizing corruption as specific concept by state officials and being busy running after the manifestations of corruption, are describable as similar tendencies.

We therefore seek a more potent theoretical focus, in the combination of financial accountability, ethical issues and organizational citizenship behaviour. We pointedly acknowledge that the accountability concept has various variants. However, among the most fundamental of these variations is certainly the notion of financial accountability. Finance is accordingly the fulcrum of what 
organizations do. It is definitely central to the pursuits of individuals and the abundance of finance, invariably introduces dynamisms, into the affairs of sundry nation states. Financial irresponsibility on the other hand is accordingly, a killer disease in the body politic of every nation and indeed, in all economic systems and every organization. It is opposite to financial accountability. But in precise terms, what is financial accountability? It means being ready and able to openly explain to others, how concerned individuals came about the funds at their disposal. It has to do with satisfactorily explaining to others (when required to do so) how we expended the monies we accessed for the benefit(s) of other person(s). It is interwoven with ethical considerations.

Let us from generalizations turn to specificities (within the context of organizations in a country) and unambiguously focus on the Nigerian public sector (the public service) as a sub-set of the national economic system. Hence, according to Ugbechie (2017), the public service in Nigeria, is describable as a house of crooks, which pillage and plunder the till, and still come out smelling like Rose flower. It is accordingly a cesspool of defiances against the rules of financial accountability and ethical standards in the country. Hence, in August 2017, the National Bureau for Statistics (NBS) in Nigeria revealed in its Corruption Survey Report, that an overwhelming percentage of Nigerians ( $95 \%$ of the citizens), will engage in the acceptance and giving of bribe. Only 5.3 per cent of Nigerians, according to the survey, will either refuse to pay a bribe when asked to or refuse a bribe if offered to them (Ibekwe et al., 2017). Thus, the obnoxious national bribe-culture in the country will certainly be sending genuine expatriateinvestors away. Invariably, bribery is both a lucrative private engagement in Nigeria and a public sector modus operandi of overseeing how national affairs are conducted. Why would the public (and even private) sector employee therefore be bordered about organizational commitment and organizational citizenship behaviour, being that the bribery engagements may translate to returns that outweigh what the organization offers as compensation and wages?

According to the report of the NBS, the estimated value of bribe paid to public officials in the country by Nigerian citizens, in the year under review, was N400 billion. This was the equivalent of $\$ 4.6 \mathrm{bn}$ in purchasing power parity (PPP), the report added (Ibekwe et al., 2017). The ideological hue of the economic system in the country indeed does not require such public officials to openly explain to others, how they came about the funds at their disposal, even with all the fights ostensibly unleashed against corruption in the national economy. We thus argue that the concept of financial accountability has become more compelling as an organizational citizenship demand in the generic Nigerian economic system, more than the seemingly optical illusion of fighting and winning a war against corruption.

\section{Reconciling the study's variables: Establishing the unpleasant nexus}

An economic system is propelled to meaningful heights by the individuals and organizations, which populate it. Invariably, organizations are given essence by the conduct of its composite individuals. Conducts that are antithetical to the principles of financial accountability and expectations of ethical excellence, would therefore, certainly accentuate the weightiness of the matters, which lead to the fragility of national economic systems. Hence, the fragility of the national economy in Nigeria is in very fundamental manner, attributable to the twin issues of lethargy towards financial accountability, and a generic objection to the imperatives of ethical conducts, in business and economic questions. It then begins to appear as if the citizens in their various organizations tend towards the thinking that things just happen, productivity just takes place, food just grows and there is abundance of it.

In 1972, the General Gowon Military regime in Nigeria, established the National Accelerated Food Production programme, the General Obasanjo administration (another military government) in 1976 introduced the Operation Feed the nation (OFN) programme, President Shehu Shagari (1979-1983) launched the Green Revolution programme and the subsequent Buhari/Idiagbon Regime brought the Go Back to Land Initiative (AbdulLateef, 2007). Then why has the nation remained a net-importer of food? The answer is very simple. In the manner of lack of financial accountability, public sector 
officials and the other sleazy individual-collaborators from the private sector must have stolen all the funds appropriated for such programmes. In the conception and operation of such policies, ethical issues must have been secondary. Programme participants must have received emoluments without cultivating any farmlands. There was certainly a lack of financial accountability in the national system.

How many Nigerian adult citizens and corporate entities pay tax as and when due? Bhatia (2008, pp.35197) has amply demonstrated the prime position of taxation in the affairs of national economies. Particularly in Bhatia (2008, pp.48-51), we see the criticality of taxation in the occlusion of (the ostensibly developing) economies from dovetailing into fragilities. It is this same crucial instrument of public revenue generation, which Nigerian citizens are seemingly averse to. But taxation and genuine citizenship behaviour are highly complementary. The usual argument of the Nigerian citizens for aversion to taxation is that the more tax-revenues availed the corrupt managers of the Nigerian economy, the more the pool of funds accessible to the sleazy public sector officials for looting. We contend however that in the complementarities of citizenship and taxation, he who pays tax is obligated to monitoring how the germane monies are expended. It seems settled therefore that citizens that fulfill their tax obligations to the state would demand financial accountability from all state officials.

What has continued to happen in the Nigerian economy is that because the state has continued to be maintained by revenues from petroleum resources, the citizens have also become aloof as to what happens to the funds allocated for development activities in the different sectors of the economy. According to Odularu (2008, p.1) in these regards, crude oil discovery in the country since 1956 has affected the Nigeria economy in both positive and adverse dimensions. In the adverse trajectories, we consider in this study, the onslaught against financial accountability by the citizens, owing to the volume of petrodollars, the oil boom entailed for the national economy. The fortunate / unfortunate scenario has invariably led to the erosion of ethical standards in the country on very massive scales and the decadence that has also occurred in the dimension of organizational citizenship behaviour. This is because, the money was perceived to be always there and things just happened for the good of the citizens.

The incidences of tax evasion and tax avoidance are invariably rife in the now embattled economy. And it is possible that the basic problems have to do with tax planning, in the face of the currently manifest fragility of the economy and the critically competing needs of the citizenry. According to Emelogu and Imoh (2013, p.306), tax planning refers to measures taken by a tax payer in order to arrange one's affairs, in such a manner as to reduce or eliminate taxes due to local, state and federal governments, while still acting within the law. Poverty of tax planning in these regards, becomes interwoven with deficiencies in organizational citizenship demands.

Then quite inappropriately, the extant contentious finances are usually referred to as taxpayers' money. Citizenship as in the context of a country's nationals and citizenship of composite organizations in a national economy are accordingly, in their combinatory forms, in deficiencies in these instances. And such deficits are contributory to the fragility of the national economy, as financial accountability and ethical questions remain profoundly eroded. Organizational citizenship behaviour has been connoted as one of the antecedents of organizational performance (Jahangir et al., 2004, p.75). This is a truism in the context of conventional formal organizations and it is also a germane declaration in the case of national economic systems. What we have consequently arrived at, is an unpleasant nexus among the study's variables. Organizational citizenship behaviour in the system, we surmise, is tainted by deplorable ethical standards, and deficient financial accountability in generic dimensions. The unpleasant scenario therefore translates to fragility in the Nigerian economic system.

We subsequently represent the input-output linkages of our theorizations in the following diagram: 


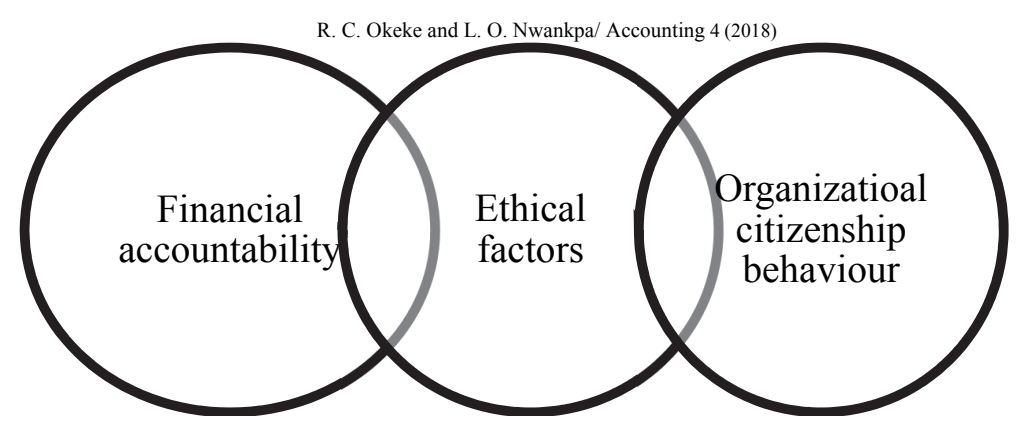

Fig. 1. A National Economic System's Input-Output Linkages of Fragility/Stability Status

We accordingly propose that the level of financial accountability in the above system is a measure of the national attitude to ethical questions. This invariably reflects generically in organizational citizenship behaviour in the country. Inversely, the quality of organizational citizenship behaviour in the economy portrays a national attitude to ethical issues. This in turn influences the generic approach of citizens towards matters of financial accountability.

It is further highlighted in this study, that the currently most celebrated national blueprint of the fight against corruption in Nigeria (from the standpoint of the governmental aficionados) is the Economic and Financial Crimes Commission (EFFCC). The commission was founded by the post-military regime of Olusegun Obasanjo in 2003, ostensibly to fight corruption. After the lengthy period of military incursions into national leadership questions in Nigeria, the autocrats in uniform seem to have surrendered power to civilian-politicians since 1999. There are still other corruption-fighting bodies, all of which are usually categorized as anti-graft agencies. Then a recent study was conducted on the effectiveness of the anti-graft agencies in the country, in their fight against corruption (Amaefule \&Umeaka, 2016). The study's hypotheses included the following: that no significant relationship exists between the activities of EFCC and economic development in Nigeria, and that the joint effect of the operations of the anti-graft agencies in the country, on the nation's economic development, is not significant. The study finally arrived at the findings / conclusions that:

- The level of fraudulent and corrupt practices in Nigeria, has become endemic and requires a well-concerted effort by government to curb.

- The operations of the anti-graft agencies established by Nigerian government within the period under review have not justified the resources provided for them.

- The present structures of these anti-graft agencies are ineffective in fighting corruption to a standstill in the Nigerian economy.

Katz (1964, p.132) in Smith, Organ \& Near (1983, p.653) had thus opined that an organization (a nation in our opinion) which depends solely upon its blueprints of prescribed behavior is a very fragile social system. Then the current blueprints of prescribed behavior in the Nigerian national economy seem to be solely according to the gospels of EFCC (and the other anti-graft fighters). And they do not appear to be winning the war. Every new regime in the country since 1999 had thus recorded more cases of public sector corruption than its predecessor in office. With each new regime, the incidence of lack of financial accountability in the Nigerian national system becomes worse, ethical issues become egregiously comatose and organizational citizenship behaviour runs immensely wild. And the national economic system remains resultantly fragile. To reverse the incidence of fragility in the Nigerian economic system therefore, financial accountability and organizational citizenship behaviour-issues in the country must be made to move beyond the orthodoxy. To achieve this indeed requires a new ethical order in the nation. 


\section{Conclusion and recommendations}

We have argued in this study that the fragility of national economic systems, otherwise denoted in this work as lack of easily identifiable ideological destinations, are functions of financial recklessness, the absence of profound ethical standards and the incidence of questionable conceptions of organizational citizenship behaviour in the country. Consequently, the gargantuan level of sleaze in the public sector in Nigeria and a national tendency towards tax avoidance and tax evasion are indicative of the demise of the culture of financial accountability in the economy. Hence, what is usually covered as corruption in the Nigerian socio-economic and public sector environment is fundamentally the death of financial accountability.

Furthermore, the study arrived at the conclusion that the negative hue of organizational citizenship behaviour in the entire Nigerian system is incontrovertibly contributory to the fragility of the national economic system. We have further argued in the work that the fragility of the Nigerian national economic system (which is representative of similar economies among developing nations) is a function of its input-output processes. A certain significance of this study therefore is in the position it has adopted that all the other theoretical frameworks of studying the pathologies of such economies are subsumable in the systems theoretical template of social science and business management investigation.

We have therefore suggested in this work that ethical regeneration is antecedent to institutional reform in the schemata of mechanisms for reversing the tendency to fragility in troubled economic systems. The relevant issues indeed transcend extant institutional structures and mechanisms. It is rather to be located in the level of organizational citizenship behaviour embedded in the economic system. This study therefore essentially finds that to reverse the trend of fragility in an economic system (a national economic system) in the context of developing economies, the issues of financial accountability, ethical questions and organizational citizenship behaviour must in their combinatory format be elevated to the status of national imperatives. All the other contradictions of this necessity would invariably lead to systemic garbage-in-garbage-out and the continuation of the phenomenon of fragility in the embattled national economic system. We recommend ethical regeneration as a national precedent to the reform of the economic system in the case study country as the two variables are in the end not antithetical to each other.

\section{References}

AbdulLateef, A. (2007). Ambodeism: The masterstrokes spearheading Nigeria's rebirth through agric. Sunday Sun, August, 20. P.54.

Asaju, K., Arome, S., \&Anyio, S. F. (2014). The rising rate of unemployment in Nigeria: the socioeconomic and political implications. Global Business and Economics Research Journal, 3(2), 1232.

Amaefule, L., \&Umeaka, E. C. (2016). Combating economic and financial crimes by the anti-graft agencies in Nigeria: Implications on the Nation's economic growth and development. International Journal of Innovative Development \& Policy Studies, 4(2), 8-33.

BBC News, (2014). Nigeria becomes Africa's biggest economy. http://www.bbc.com/news/business26913497.

BBC News (2016). Nigerian economy slips into recession http://www.bbc.com/news/business$\underline{37228741 .}$.

Bhatia, H.L. (2008). Public Finance. 26th Edition. New Delhi, India: Vikas Publishing House.

Bogdanov, A. (1922). Tektologiya: VseobschayaOrganizatsionnayaNauka, 3 volumes. Berlin and Petrograd-Moscow.

Bogdanov, A. 1980. Essays in Tektology: The General Science of Organization, Trans. By George Gorelik. Seaside: Intersystems Publications. 
Capra, F. (1997). The web of life. New York: Doubleday-Anchor Book.

Das Hara, H \&Chouldbury, B.C. (1997). Introduction to political sociology. New Delhi: Vika Publishing House.

DTN (2017). Nigeria's Corruption Caused Buhari's Ill Health - Umenzekwe, APC Chieftain. https://dailytimes.ng/opinion/nigerias-corruption-caused-buharis-ill-health-umenzekwe-apcchieftain/

Ekpo, C. E., Chime, J., \&Enor, F. N. (2016). The irony of Nigeria's fight against corruption: An appraisal of President Muhammadu Buhari's first eight months in office. International Journal of History and Philosophical Research, 4(1), 61-73.

Emelogu, L.C \&Imoh, B.C. (2013). Principles and Practice of Advanced Taxation. Aba, Nigeria: Diplomacy Group.

Ibekwe, N, Udo, B, Olawoyin, O. (2017). 95\% of Nigerians indulge in bribery - NBS

http://www.premiumtimesng.com/news/headlines/240517-95-nigerians-indulge-bribery-nbs.html

Izueke, E.M.C. (2014). Some theoretical frameworks of analysis in public administration. In Ikeanyibe, O.M \&Mbah, P.O. (Eds.). An anthology of theories for social research, Nsukka, Nigeria: University of Nigeria Press.

Ishaq, R.M. (2014). Civil Service and the Challenge of Productivity in Nigeria, International Letters of Social and Humanistic Sciences, 14(-), 37-44.

Jahangir, N., Akbar, M. M., \&Haq, M. (2004). Organizational citizenship behavior: Its nature and antecedents. BRAC University Journal, 1(2), 75-85.

Katz, D. (1964). The motivational basis of organizational behavior. Behavioral Science, 9(2), 131-133.

Laszlo, E. (1996). The Systems View of the World: A Holistic Vision for Our Time. New Jersy: Hampton Press.

Mbah, P. (2014). Political science theories and their application in political science research. In Ikeanyibe, O.M \&Mbah, P.O. (Eds.). An anthology of theories for social research, Nsukka, Nigeria: University of Nigeria Press.

Mele, C., Pels, J., \&Polese, F. (2010). A brief review of systems theories and their managerial applications. Service Science, 2(1-2), 126-135.

Meadows, D.H. (2008). Thinking in Systems: A Primer, Vermont: Chelsea Green.

Odularu, G.O. (2008). Crude oil and the Nigerian economic performance. Oil and Gas Business, 129.https://scholar.google.com/citations?user=6InRybEAAAAJ\&hl=en.

Oladeinde, A. (2017). Electricity truly not rocket science. Sunday Sun (Nigeria), August, 20, p.50.

Onuoha, J. (2008). The state and economic reforms in Nigeria: An exploratory note on the capture theory of politics. Nsukka, Nigeria: AP Express

Organ, D.W. (1997).Organizational citizenship behavior: It's constructclean-up time. Human Performance, 10 (2), 85-97.

Salauden, O. (2017). How it all started. Sunday Sun, Nigeria, August 20, p.7.

Smith, C. A., Organ, D. W., \& Near, J. P. (1983). Organizational citizenship behavior: Its nature and antecedents. Journal of applied psychology, 68(4), 653-663.

Stichweh, R. (2011). Systems theory. International Encyclopedia of Political Science. New York: Sage.

Takeuchi, R., Bolino, M. C., \& Lin, C. C. (2015). Too many motives? The interactive effects of multiple motives on organizational citizenship behavior. Journal of Applied Psychology, 100(4), 1239.

Ugbechie, K. (2017). Every day is bribe. Sunday Sun (Nigeria), August, 20, p.30.

Von Bertalanffy, L. (1972). The history and status of general systems theory. Academy of Management Journal, 15(4), 407-426.

Von Bertalanffy, L. (1968). General System theory: Foundations, Development, Applications. New York: George Braziller.

Von Bertalanffy, L. (1951). Problems of general systems theory: A new approach to unity of science. Human Biology, 23(4), 302-312.

Walz, S.M \&Niehoff, B.P. (1996).Organizational citizenship behaviours and their effect on organizational effectiveness in limited menu restaurants. Best Paper Proceedings, Academy ofManagement conference, pp. 307-311. 


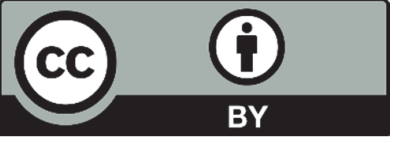

(C) 2018 by the authors; licensee Growing Science, Canada. This is an open access article distributed under the terms and conditions of the Creative Commons Attribution (CC-BY) license (http://creativecommons.org/licenses/by/4.0/). 